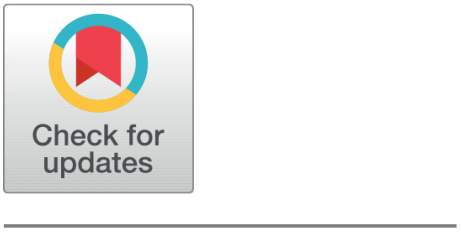

OPEN ACCESS

Received: 22.04.2021

Accepted: 21.05.2021

Published: 04.06.2021

Citation: Ashwini K, Rao PS (2021) The influence of adding alccofine and nano-silica on the behavior of concrete at elevated temperatures. Indian Journal of Science and Technology 14(20): 1647-1660. https ://doi.org/10.17485/IJST/v14i20.694

* Corresponding author.

ashwini.kota@gmail.com

Funding: None

Competing Interests: None

Copyright: ๑ 2021 Ashwini \& Rao. This is an open access article distributed under the terms of the Creative Commons Attribution License, which permits unrestricted use, distribution, and reproduction in any medium, provided the original author and source are credited.

Published By Indian Society for Education and Environment (iSee)

ISSN

Print: 0974-6846

Electronic: 0974-5645

\section{The influence of adding alccofine and nano-silica on the behavior of concrete at elevated temperatures}

\author{
K Ashwini ${ }^{1 *}$, P Srinivasa Rao² \\ 1 Research scholar, Department of Civil Engineering, Jawaharlal Nehru Technological \\ University, Hyderabad, 500085, Telangana, India \\ 2 Professor, Department of Civil Engineering, Jawaharlal Nehru Technological University, \\ Hyderabad, 500085, Telangana, India
}

\section{Abstract}

Objectives: To investigate the influence of adding alccofine and nano-silica as an additive on the behavior of concrete at elevated temperatures. Methods: Concrete specimens with and without nano-silica and alccofine were heated to temperatures of $200^{\circ} \mathrm{C}$ to $1000^{\circ} \mathrm{C}$ for 4,8 , and 12 hours. In this study, relative compressive strength and ultrasonic pulse velocity were investigated. Using regression analysis, a relation between compressive strength and temperature was derived and compared with other relations. Findings: The outcomes demonstrated that elevated temperatures degraded the microstructure of concrete and reduced the relative compressive strength and ultrasonic pulse velocity. The percentage of degradation was higher in nano-silica and alccofine concrete at $1000^{\circ} \mathrm{C}$. The proposed relation was found accurate compared to other relations. Novelty/Applications:As the temperature increases above $600^{\circ} \mathrm{C}$, control mixes performed better than the concrete mixes using nanosilica and alccofine.

Keywords: concrete; alccofine; nanosilica; fire resistance; ultrasonic pulse velocity

\section{Introduction}

The destruction of life or property is caused by fire in buildings and infrastructure ${ }^{(1)}$. Since ordinary concrete is regarded as the primary material in buildings and structures all over the world, there is a significant need to fully comprehend the impact of flame on concrete $^{(1)}$. Many authors have examined and recorded the action of concrete against fire, and it has been discovered that concrete is fire resistant ${ }^{(2)}$. Concrete behavior at high temperatures is determined by its material properties, heating intensity, and high temperature. During several heating situations, the key damaging factors are C-S-H gel degradation, the thermal imbalance between the cement paste and aggregate, and pore water pressure inside the concrete $\mathrm{mix}^{(3)}$. Understanding the morphology and chemical processes of the hardened concrete produced by the hydration of cement is critical for ensuring the best use of additives in concrete ${ }^{(4)}$. Concrete buildings need to be assessed after intense fire ${ }^{(5)}$. 
Furthermore, wholly evolved fires trigger structural part expansion, leading to strains and stresses that should be avoided ${ }^{(6)}$. The goal of a post-fire exploration is to figure out how much damage there was and how dense the fire-damaged concrete is still. Even then, after a severe fire, evaluation of the overall safety condition is needed to make the best judgment on the structural fixing, reconstruction, or strengthening plan to be used as an option to demolition ${ }^{(5,7)}$. Most building elements subjected to elevated temperatures resulting from the fire have deteriorated; it might or might not be noticeable ${ }^{(8)}$. The assessment of damaged concrete can be done in two ways. The first one is the direct method by determining the residual compressive strength. The indirect method uses ultra-sonic pulse velocity (UPV) test and microstructural analysis to know the quality of the fire-damaged concrete. The use of assumed tests for compressive strength of concrete employing NDT tests is preferred in terms of structure protection in fire and the ease with which data concerning the fire situation can be collected ${ }^{(9)}$. Numerous nondestructive techniques are often used to evaluate concrete loss and degradation after subjected to a fire, but UPV and rebound hammer $(\mathrm{RH})$ tests can be effectively used to measure residual strength after fire ${ }^{(10,11)}$. The ultrasonic approach is widely used to assess the durability of concrete buildings in place ${ }^{(12,13)}$. Chemical changes and physical changes in concrete morphology under such scenarios significantly impact its mechanical characteristics ${ }^{(14,15)}$. Even though the precision of predicting compressive strength via UPV is not high, a relative decrease in UPV, regularly assessed in a concrete specimen exposed to elevated heating, can be used to identify the occurrence of defects in concrete ${ }^{(16,17)}$.

It is essential to understand the strength and decomposition properties of concrete using additives subjected to elevated temperatures in order to assess the reaction of those structures during and after susceptibility to high temperatures ${ }^{(18)}$. The current paper examines the characteristics of concrete using nano-silica and alccofine at elevated temperatures, focusing on the compressive strength, ultrasonic pulse velocity, and derivation of relation between compressive strength and temperature.

\section{Materials and Methods}

\subsection{Cement}

Ordinary Portland cement of 53 grade was procured from local suppliers. The standard consistency of cement is 32 percent, and the initial setting time and final setting time are 56 and 259 minutes. The properties of cement are shown in Table 1.

Table 1. Physical properties of Cement

\begin{tabular}{lllllll}
\hline Standard Consistency & Specific gravity & Final setting time & Initial setting time & Fineness & $\begin{array}{l}\text { Soundness } \\
\text { method) }\end{array}$ & $\begin{array}{l}\text { (Le } \\
\text { Chatelier }\end{array}$ \\
\hline$(\%)$ & - & $(\mathrm{min})$ & $(\mathrm{min})$ & $\left(\mathrm{m}^{2} / \mathrm{kg}\right)$ & $(\mathrm{mm})$ & 1.2 \\
32 & 3.15 & 259 & 56 & 300 & 1.2 \\
\hline
\end{tabular}

\subsection{Fine aggregate (FA) and coarse aggregate (CA)}

Sand confirming to Zone -II was used as fine aggregate, and additional materials, if any, are removed from sand by passing it through a sieve size of $4.75 \mathrm{~mm}$. Crushed stone of $20 \mathrm{~mm}$ size is used as coarse aggregate. Fine and coarse aggregates were brought from local suppliers. Physical characteristics of fine and coarse aggregates are given in Table 2.

Table 2. Physical characteristics of fine and coarse aggregates

\begin{tabular}{lll}
\hline Properties & FA & CA \\
\hline Fineness modulus & 3.18 & 7.6 \\
Specific gravity & 2.65 & 2.79 \\
Bulk-density $\left(\mathrm{kg} / \mathrm{m}^{3}\right)$ & 1520 & 1416 \\
\hline
\end{tabular}

\subsection{Nano silica and alccofine}

Nano silica of average particular size $17 \mathrm{~nm}$ was procured from Asstra chemicals, Chennai, India. Alccofine of size $4-6 \mu \mathrm{m}$ was obtained from local dealers. The properties of nano-silica (Ns) and alccofine (Al) are given in Table 3. 
Table 3. Chemical and physical properties of materials

\begin{tabular}{lll}
\hline Item & $\mathrm{Ns}$ & $\mathrm{Al}$ \\
\hline Calcium oxide & $0.06 \%$ & $32.1-34.3 \%$ \\
Silicon dioxide & $99.88 \%$ & $33-35 \%$ \\
Aluminum oxide & $0.01 \%$ & $18.0-20.0 \%$ \\
Ferric oxide & $0.00 \%$ & $1.8-2 \%$ \\
Magnesium oxide & - & $8.0-10.0 \%$ \\
Sulfur trioxide & - & $0.30-0.70 \%$ \\
Avg. particle size & $17 \mathrm{~nm}$ & $4-6 \mu \mathrm{m}$ \\
\hline
\end{tabular}

\subsection{Superplasticizer and water}

Conplast SP430 DIS, with brand name Fosroc, is a brown liquid that is immediately soluble in water and is based on Sulphonated Naphthalene Polymers to improve the workability of concrete. It is combined with water and added to the concrete.

\section{Research methodology}

Mix design of three concrete grade M40, M50, \& M60 was done using according to the IS10262:2019 and IS 456:2005. In this study, the comparison of control mixes and mixes using nano-silica and alccofine was made. The percentage of nano-silica and alccofine is taken as $15 \%$ and $3 \%$. The mix proportions of all the mixes are given in Table 4 . A total of 324 cubic samples of size $150 \mathrm{~mm}$ were cast and cured in water for 28 days, with three samples from each mix. Then all the samples were removed from the curing tank, dried, and then subjected to room temperature, $200,400,600,800, \& 1000{ }^{\circ} \mathrm{C}$ temperatures for the fire period of 4, 8, \& 12 hrs electric furnace as shown in Figure 1. After that, the samples were allowed to cool in the open air until they reached room temperature. The heating \& cooling rate details are presented in Figure 4 . All the samples were first measured for ultrasonic pulse velocity using the ultrasonic pulse velocity test apparatus shown in Figure 2. Then same samples were put in the compression testing system shown in Figure 3 to determine compressive strength. The relative compressive strength and derivation of relation between relative compressive strength and temperature were done. The flowchart of the experimental procedure is shown in Figure 5.

Table 4. Mix proportions (for $1 \mathrm{~m} 3$ ) and notations of different mixes

\begin{tabular}{|c|c|c|c|c|c|c|c|c|c|}
\hline Mix & SCM & $\begin{array}{l}\text { Nota- } \\
\text { tions }\end{array}$ & $\begin{array}{l}\text { Water } \\
(\mathrm{Kg} / \mathrm{m} 3)\end{array}$ & $\begin{array}{l}\text { Cement } \\
(\mathrm{Kg} / \mathrm{m} 3)\end{array}$ & $\begin{array}{l}\text { Fine agg. (FA) } \\
(\mathrm{Kg} / \mathrm{m} 3)\end{array}$ & $\begin{array}{l}\text { Coarse agg. (CA) } \\
(\mathrm{Kg} / \mathrm{m} 3)\end{array}$ & $\begin{array}{l}\text { Alccofine (AL) } \\
(\mathrm{Kg} / \mathrm{m} 3)\end{array}$ & $\begin{array}{l}\text { Nano silica (NS) } \\
(\mathrm{Kg} / \mathrm{m} 3)\end{array}$ & $\mathrm{w} / \mathrm{c}$ \\
\hline \multirow[t]{2}{*}{ M40 } & 0 & M4 & 160 & 400 & 667 & 1248 & - & - & 0.4 \\
\hline & $\mathrm{AL}+\mathrm{Ns}$ & M4AlNs & 160 & 328 & 667 & 1248 & 60 & 12 & 0.4 \\
\hline \multirow[t]{2}{*}{ M50 } & 0 & M5 & 159 & 440 & 642 & 1243 & - & - & 0.36 \\
\hline & $\mathrm{AL}+\mathrm{Ns}$ & M5AlNs & 159 & 360.8 & 642 & 1243 & 66 & 13.2 & 0.36 \\
\hline \multirow[t]{2}{*}{ M60 } & 0 & M6 & 158 & 527 & 596 & 1218 & - & - & 0.3 \\
\hline & $\mathrm{AL}+\mathrm{Ns}$ & M6AlNs & 158 & 432.2 & 596 & 1218 & 79 & 15.8 & 0.3 \\
\hline
\end{tabular}

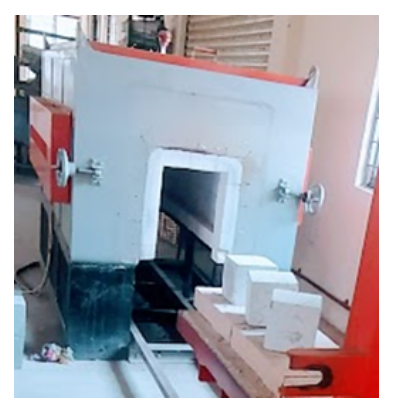

Fig 1. Samples placed in electric furnace 


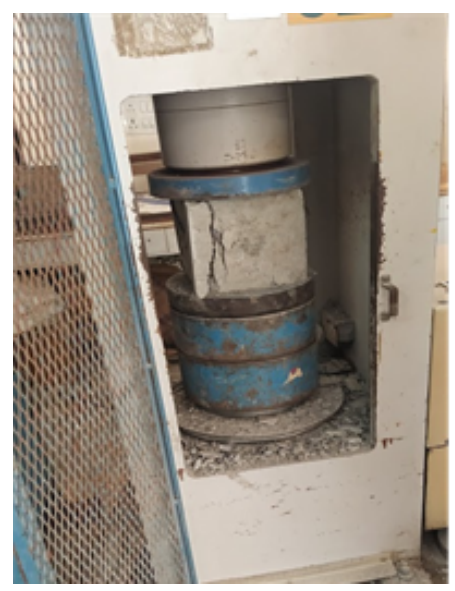

Fig 2. Compression testing machine

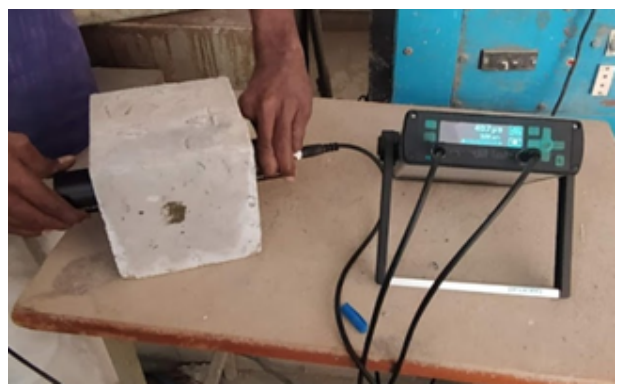

Fig 3. Ultrasonic pulse velocity measurement of concrete samples

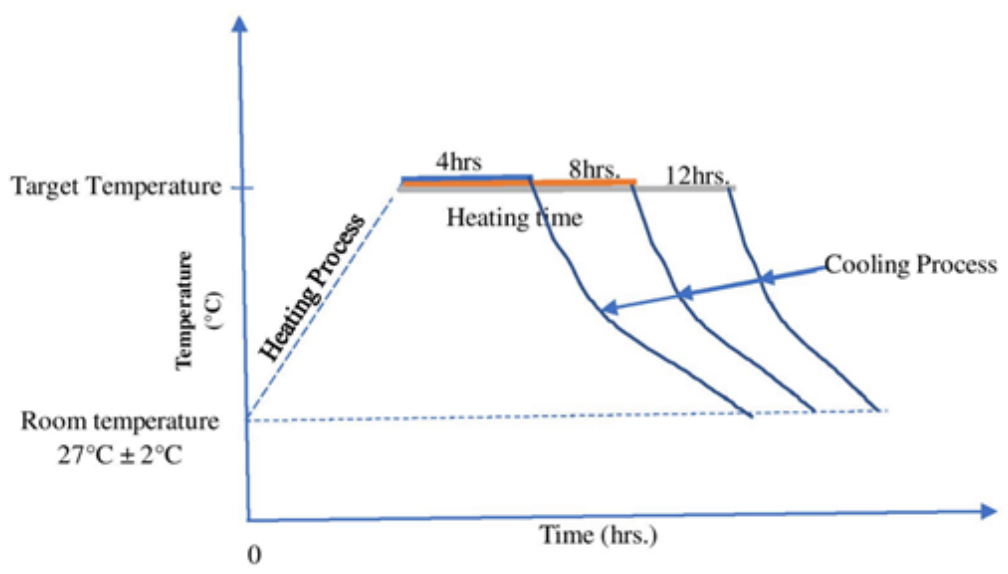

Fig 4. Heating \& cooling rate 


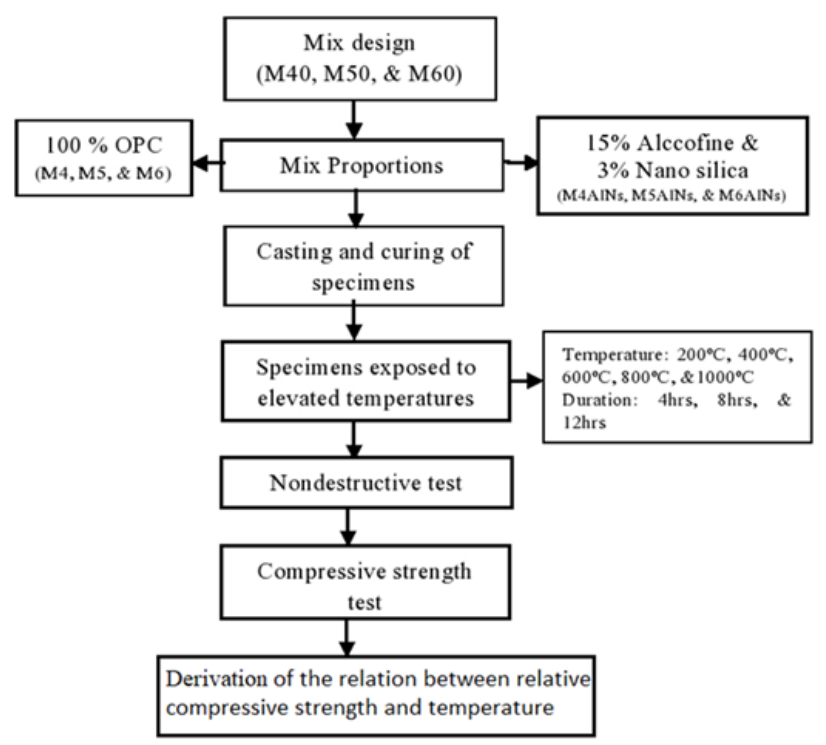

Fig 5. Flowchart of the experimental procedure

\section{Results and Discussion}

\subsection{Relative compressive strength}

Relative compressive strength (RCS) is the ratio of compressive strength at a particular temperature to compressive strength at room temperature. Relative compressive strength values of the concrete blends at different temperatures and fire durations are demonstrated in Figures 6,7 and 8 . At $200^{\circ} \mathrm{C}$ after $4 \& 8$ hours of heating, the RCS was greater than 1, indicating an increase in strength for both control and $\mathrm{Al}+\mathrm{Ns}$ mixes. If the temperature rises, water from the binder structure evaporates, improving the cement paste and increasing concrete strength. Thus, $\mathrm{Al}+\mathrm{Ns}$ mixes with dense microstructures have a relatively low increase in strength due to less vaporization of water and increased pore pressure ${ }^{(19)}$. The M4 and M6 mix showed the highest RCS of 1.15 at $200^{\circ} \mathrm{C}$. The vaporization of water from the voids reduced RCS from 1 to 0.89 at $400^{\circ} \mathrm{C}$ as fire length increased from 4 to 8 hours. The control mixes M4, M5, and M6 have an RCS of 1 to 0.93, and M4AlNs, M5AlNs, and M6AlNs mixes with an RCS of 0.98 to 0.89 . The coefficients of thermal expansion of cement paste and aggregate also play a role in the loss of strength with temperature $^{(20)}$.

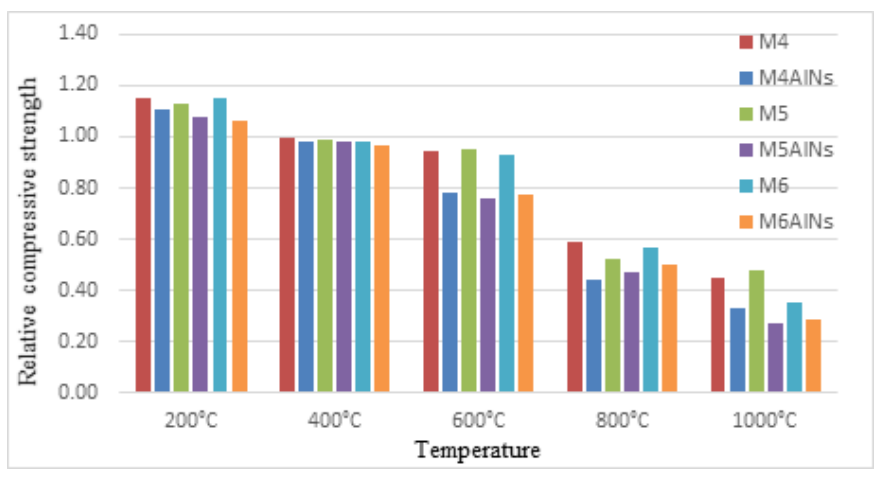

Fig 6. Relative compressive strength Vs. temperature for 4 hrs fire duration 


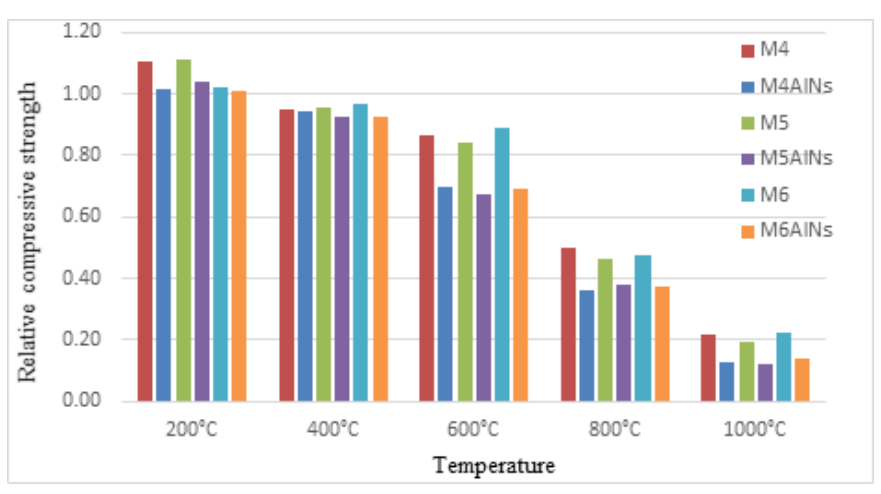

Fig 7. Relative compressive strength Vs. temperature for $8 \mathrm{hrs}$ fire duration

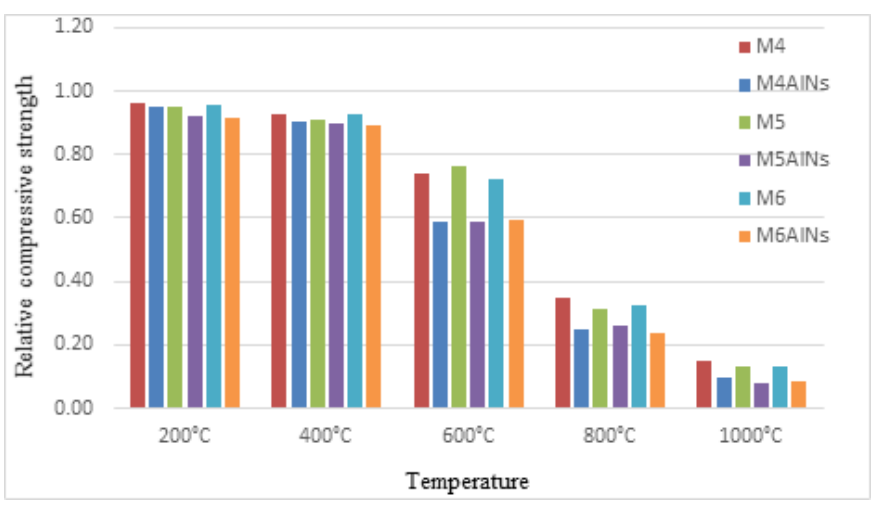

Fig 8. Relative compressive strength Vs. temperature for $12 \mathrm{hrs}$ fire duration

Furthermore, as the fire duration at $600^{\circ} \mathrm{C}$ increased, the RCS of M4, M5, and M6 mixes ranged from 0.95 to 0.72 . While M4AlNs, M5AlNs, and M6AlNs mixes ranged from 0.78 to 0.59 . At $800^{\circ} \mathrm{C}$, the RCS of all the concrete mixes was less than 0.6 . And the RCS subsequently decreased to 0.24 for the Al+Ns mix and 0.32 for the control mix at 12 hours. The dense morphology is mainly impervious, which is harmful at high temperatures. It prevents water from escaping, contributing to the development of pore water pressure and thereby leading to microcrack formation, resulting in rapid degradation of RCS ${ }^{(21)}$. At $1000^{\circ} \mathrm{C}$, the RCS was between 0.48 and 0.27 after 4 hours. When the fire duration increased to 8 hours, the values were half of what they were after 4 hours. As fire duration increased to 12 hours, the strength was between $0.15 \& 0.08$ because of the increase in microcracks, as shown in Figure 9. Beyond $400^{\circ} \mathrm{C}$, the M4AlNs, M5AlNs, and M6AlNs mixes were the most affected by fire, and this degradation may be attributed to the decomposition of C-S-H hydrates. As a result, it can be concluded that RCS of M4AINs, M5AlNs, and M6AlNs mixes was less compared to M4, M5, and M6 at all temperatures due to the pore water pressure development in compact morphology $\mathrm{Al}+\mathrm{Ns}$ mixes ${ }^{(21)}$.

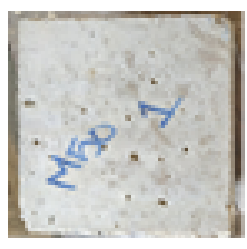

$200^{\circ} \mathrm{C}$

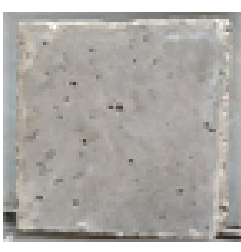

$400^{\circ} \mathrm{C}$

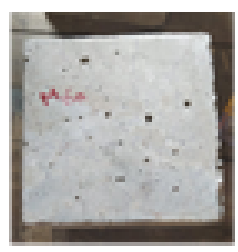

$600^{\circ} \mathrm{C}$

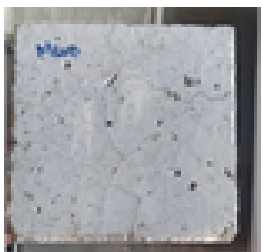

$800^{\circ} \mathrm{C}$

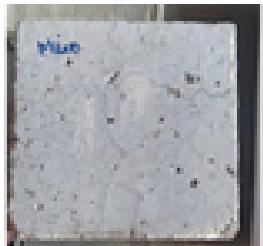

$1000^{\circ} \mathrm{C}$

Fig 9. Visual appearance of samples exposed to temperatures of $200^{\circ} \mathrm{C}, 400^{\circ} \mathrm{C}, 600^{\circ} \mathrm{C}, 800^{\circ} \mathrm{C}, \& 1000^{\circ} \mathrm{C}$ 


\subsection{Ultrasonic pulse velocity}

Ultrasonic Pulse Velocity test is one of the most powerful and versatile indirect techniques used for assessing the damage level in concrete subjected to fire, regarding the loss of strength and durability ${ }^{(22)}$. Because of its flexibility in gathering data about the fire situation, using the UPV test for estimating the compressive strength of concrete is recommended. Figures 10,11 and 12 shows UPV test results of concrete specimens subjected to a temperature of $200^{\circ} \mathrm{C}$ to $1000^{\circ} \mathrm{C}$. Due to higher temperatures, the micro-structures of the concrete specimens used in the investigation deteriorated, resulting in reduced UPV values. The quality of concrete specimens in terms of internal flaws, cracks, and uniformity can be evaluated with the help of guidelines given in IS 13311 (Part 1): 1992 . When exposed to a fire for $4 \& 8$ hours at $200^{\circ} \mathrm{C}$, except for M6 and M6AlNs mixes, which showed improved UPV values, all concrete mixes had UPV values greater than 4.5 even after reduction. As a result, the concrete quality remained excellent, consistent with compressive strength results, which showed an increase in strength at $200^{\circ} \mathrm{C}$ from Fig. 7, 8. UPV values were between 3.5 and $4.5 \mathrm{Km} / \mathrm{sec}$ at $200^{\circ} \mathrm{C}$ for 12 hours and $400^{\circ} \mathrm{C}$ for 4 and 8 hours, suggesting that the concrete was of good quality and signaling a decrease in strength and change in microstructure. At $600^{\circ} \mathrm{C}$, UPV values decreased by 63 to 69 percent. The reduction was relatively similar for all concrete mixes except M4, which showed a lower reduction, and M6AlNs showed a higher reduction. And as the fire duration rose to 8 and 12 hours, the percent reduction increased further by 4 to $8 \%$ and 8 to $17 \%$, respectively. The UPV values were reduced by 92 to $99 \%$ at $800^{\circ} \mathrm{C}$ with increased fire duration. The reduction percentage was higher for M4AlNs, M5AlNs, and M6AlNs mixes due to the more porous structure generated by CSH gel disintegration. From Fig. 10, 11, \& 12, the further increase in temperature and fire duration, UPV values decreased dramatically and finally reduced to zero at $1000^{\circ} \mathrm{C}$. As the rapid rise in temperature triggers dehydration of calcium silicate hydrate(C-S-H), significant changes in porosity and permeability of concrete occurs and leads to the development of microcracks ${ }^{(23)}$ in concrete which causes a reduction in transmission speed of sound waves passing through concrete specimens ${ }^{(24)}$.

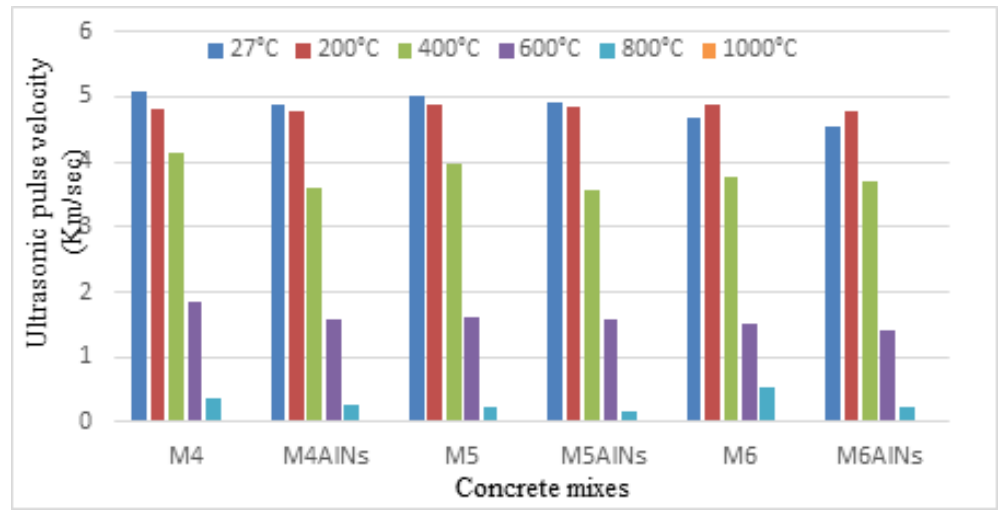

Fig 10. Ultrasonic pulse velocity at different temperature for 4 hrs fire duration

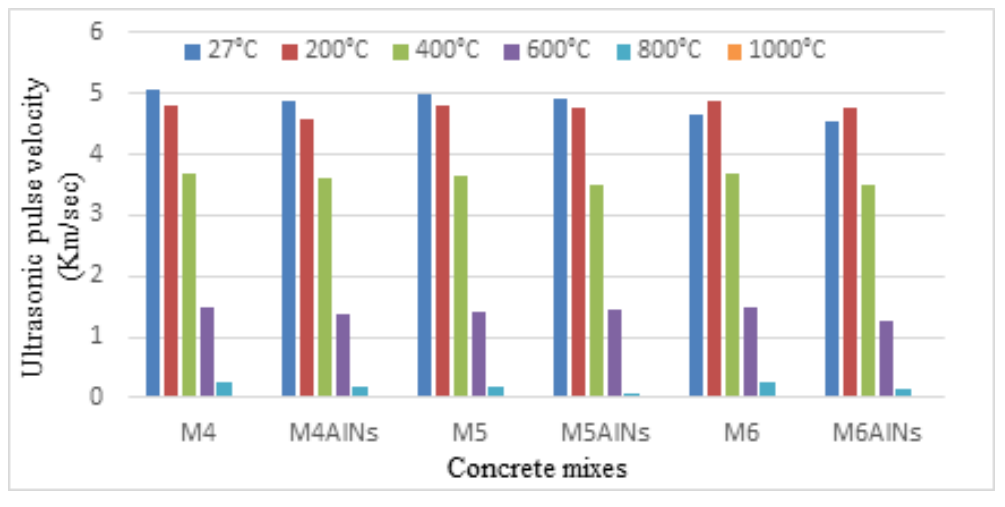

Fig 11. Ultrasonic pulse velocity at different temperature for 8 hrs fire duration 


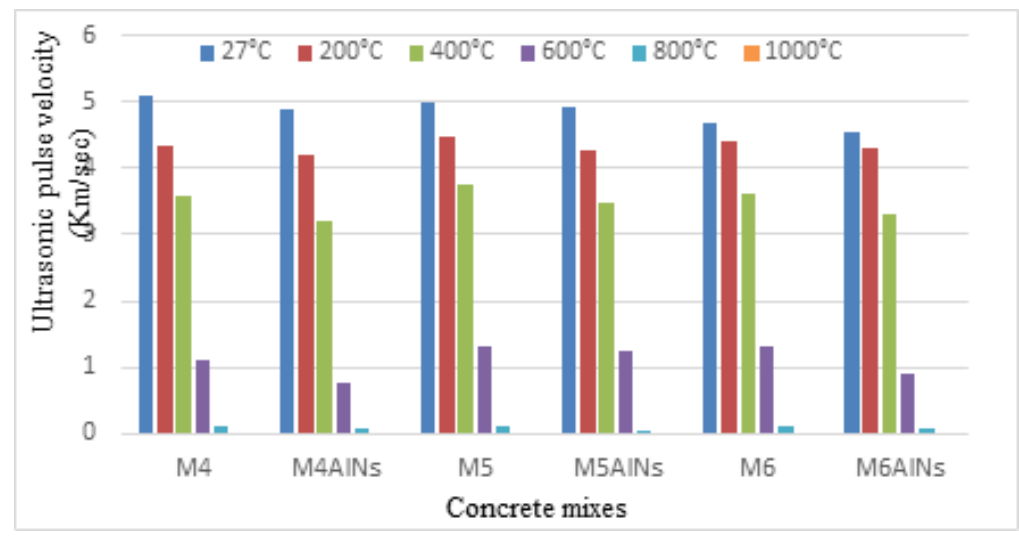

Fig 12. Ultrasonic pulse velocity at different temperature for $12 \mathrm{hrs}$ fire duration

\subsection{The proposed relationships between compressive strength \& temperature}

Developing a mathematical relationship for calculating concrete residual compressive strength at higher temperatures is a valuable technique for designing concrete structures ${ }^{(25)}$. Since the majority of the relationships were based on cylindrical residual compressive strength, regression methods were used to create a relationship between relative cylindrical compressive strength and temperature for various concrete mixes. The cylindrical compressive strength was calculated by multiplying cube compressive strength with 0.8 according to BS 1881: Part 120:1983 ${ }^{(26)}$. Furthermore, since most of the relationships derived were based on a constant fire period of 30 minutes to 4 hours, the proposed relation was developed for concrete specimens subjected to a fire duration of 4 hours in this study ${ }^{(19,21,27,28)}$. The proposed equations in the polynomial form shown in Table 6 \& Figures 13,14 and 15 are established to evaluate the residual compressive strength at various temperature exposures. The proposed equations showed acceptable reliability since correlation coefficient $\mathrm{R}^{2}$ is between 0.89 to 0.98 for all the concrete mixes ${ }^{(29)}$. Table 5 summarizes the relations developed by others researchers to calculate residual compressive strength at different temperatures. The proposed relation was compared to the relation proposed by Eurocode and various types of relations formed by other researchers, such as 1,2, and 3-degree polynomial relations.

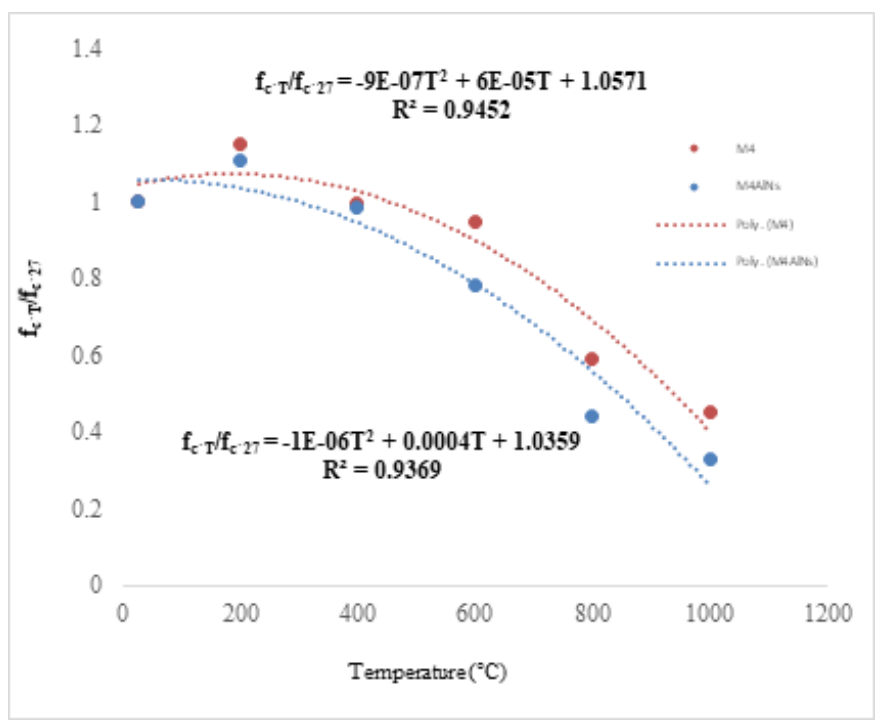

Fig 13. Correlation between temperature and $\mathrm{f}_{c^{\prime} T} / \mathrm{f}_{c^{\prime} 27}$ for M4 \& M4AlNs mix 


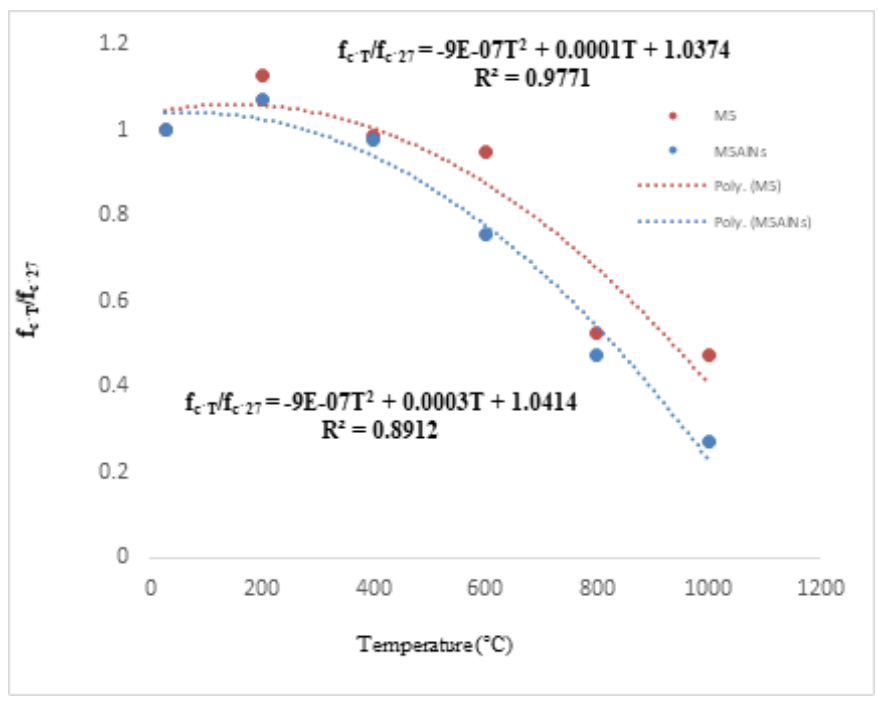

Fig 14. Correlation between temperature and $\mathrm{f}_{c^{\prime} T} / \mathrm{f}_{c^{\prime} 27}$ for M5 \& M5AlNs mix

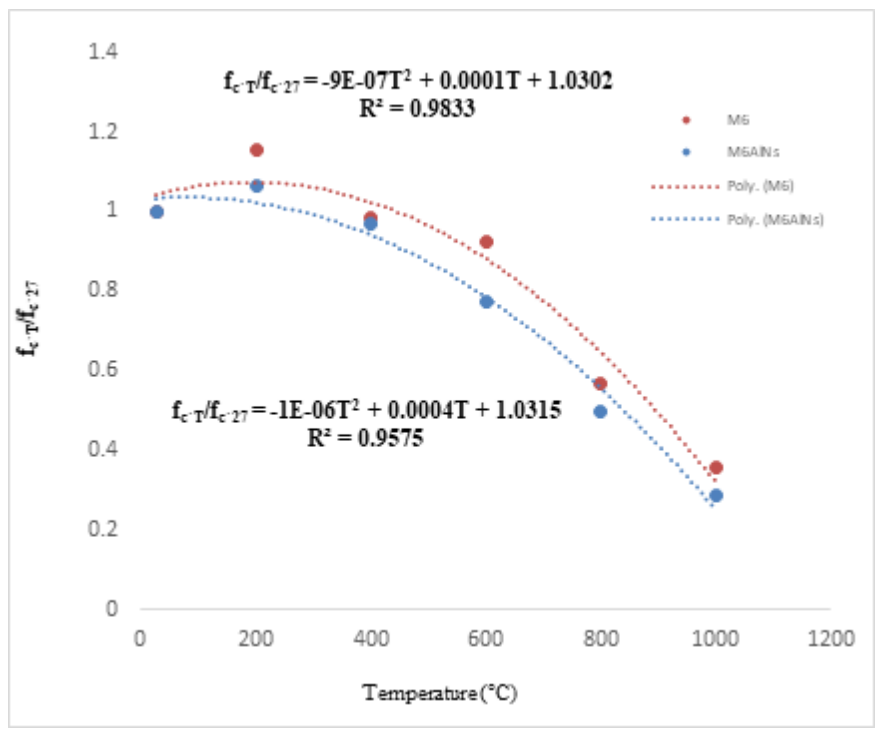

Fig 15. Correlation between temperature and $\mathrm{f}_{c^{\prime} T} / \mathrm{f}_{c^{\prime} 27}$ for M6 \& M6AlNs mix

Table 5. Relations from code of practice and other researchers

\begin{tabular}{|c|c|}
\hline Source & Relations \\
\hline Eurocode et al. ${ }^{(27)}$ & $\begin{array}{l}\mathrm{f}_{c^{`} T}=\mathrm{f}_{c^{\prime}}, \mathrm{T} \leq 100 \circ \mathrm{C} \\
\mathrm{f}_{c^{`} T}=\mathrm{f}_{c^{\star}} \times(1.067-0.00067 \times \mathrm{T}) \geq 0,100 \leq \mathrm{T} \leq 400 \circ \mathrm{C} \\
\mathrm{f}_{c^{`} T}=\mathrm{f}_{C^{\natural}} \times(1.44-0.0016 \times \mathrm{T}) \geq 0, \mathrm{~T} \geq 400^{\circ} \mathrm{C}\end{array}$ \\
\hline Raza et al. ${ }^{(19)}$ & $\mathrm{f}_{c^{\prime} T}=\mathrm{f}_{c^{\prime}}\left(-3 \mathrm{E}-06 \mathrm{x}^{2}+0.0014 \mathrm{x}+0.9365\right), 25 \leq \mathrm{T} \leq 800^{\circ} \mathrm{C}$ \\
\hline Li and Purkiss et al. ${ }^{(28)}$ & $\mathrm{f}_{c^{`} T}=\mathrm{f}_{c^{`}} \times\left(0.00165 \times\left(\frac{T}{100}\right)^{3}-0.03 \times\left(\frac{T}{100}\right)^{2}+0.025 \times\left(\frac{T}{100}\right)+1.002\right)$ \\
\hline Hassan et al. ${ }^{(30)}$ & $\mathrm{f}_{c^{\prime} T}=\left(20731.45 \mathrm{xf}_{c^{\natural}}+11.76 \times \mathrm{T}^{1.708}\right) /\left(20731.45+\mathrm{T}^{1.708}\right), 20 \leq \mathrm{T} \leq 800^{\circ} \mathrm{C}$ \\
\hline
\end{tabular}


Table 6. Proposed Relations for different concrete mixes

\begin{tabular}{lll}
\hline Concrete mix & Relation & $\mathrm{R}^{2}$ \\
\hline M4 & $\mathrm{f}_{c^{\prime}} / \mathrm{f}_{c^{\prime} 27}=-9 \mathrm{E}-07 \mathrm{~T}^{2}+6 \mathrm{E}-05 \mathrm{~T}+1.0571$ & 0.9452 \\
M4AlNs & $\mathrm{f}_{c^{\prime} T} / \mathrm{f}_{c^{\prime} 27}=-1 \mathrm{E}-06 \mathrm{~T}^{2}+0.0004 \mathrm{~T}+1.0359$ & 0.9369 \\
M5 & $\mathrm{f}_{c^{\prime}} / \mathrm{f}_{c^{\prime} 27}=-9 \mathrm{E}-07 \mathrm{~T}^{2}+0.0001 \mathrm{~T}+1.0374$ & 0.9771 \\
M5AlNs & $\mathrm{f}_{c^{\prime}} / \mathrm{f}_{c^{\prime} 27}=-9 \mathrm{E}-07 \mathrm{~T}^{2}+0.0003 \mathrm{~T}+1.0414$ & 0.8912 \\
M6 & $\mathrm{f}_{c^{\prime}} / \mathrm{f}_{c^{\prime} 27}=-9 \mathrm{E}-07 \mathrm{~T}^{2}+0.0001 \mathrm{~T}+1.0302$ & 0.9833 \\
M6AlNs & $\mathrm{f}_{c^{\prime} T} / \mathrm{f}_{c^{\prime} 27}=-1 \mathrm{E}-06 \mathrm{~T}^{2}+0.0004 \mathrm{~T}+1.0315$ & 0.9575 \\
\hline
\end{tabular}

Compared to other relations, Figures 16,17, 18, 19, 20 and 21 showed that the proposed relation's values were approximately equal to experimental values. The values obtained from Raza et al. ${ }^{(19)}$ relation was approximately comparable to predicted values up to $600^{\circ} \mathrm{C}$, with the amount of similarity was more remarkable for the M4AlNs, M5AlNs M6AlNs mixes. At $200^{\circ} \mathrm{C}$, all other relations except Raza et al. ${ }^{(19)}$ relation showed a decrease in residual compressive strength for all the concrete blends. The values determined using the existing Eurocode relation ${ }^{(27)}$ for all the concrete blends were lower than predicted, and experimental values and a decrease in residual compressive strength were observed at $200^{\circ} \mathrm{C}$.

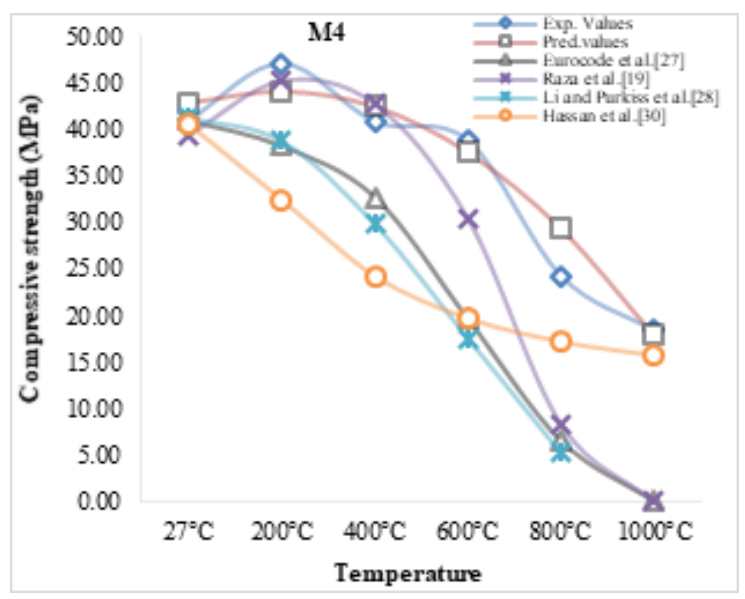

Fig 16. Compressive strength calculated from different relations w.r.t temperature for M4 mix

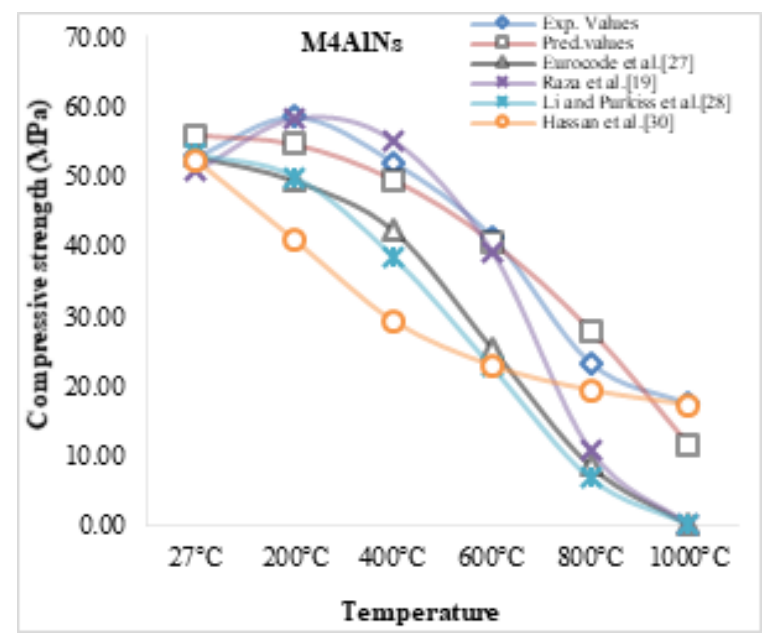

Fig 17. Compressive strength calculated from different relations w.r.t temperature for M4AlNs mix 


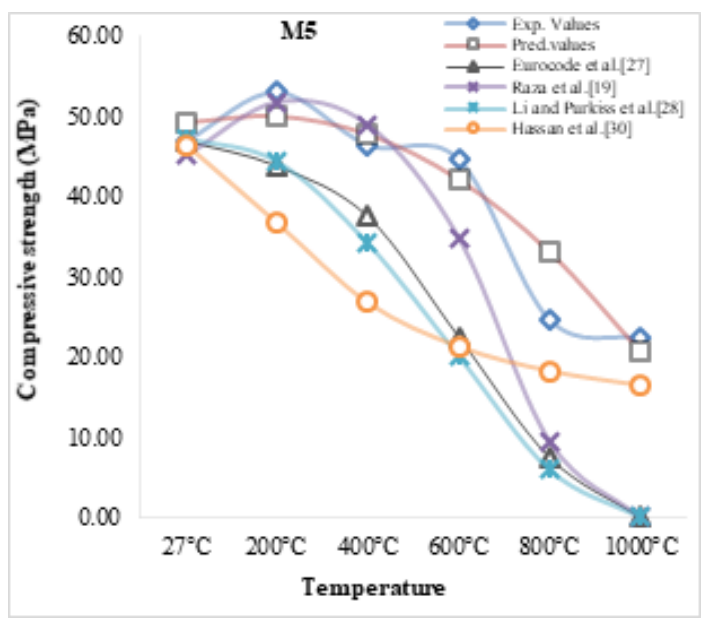

Fig 18. Compressive strength calculated from different relations w.r.t temperature for M5 mix

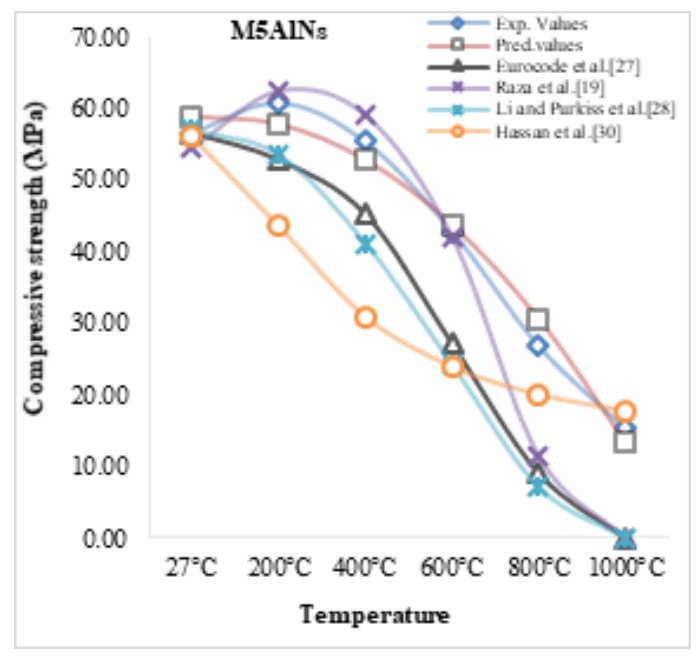

Fig 19. Compressive strength calculated from different relations w.r.t temperature for M5AlNs mix

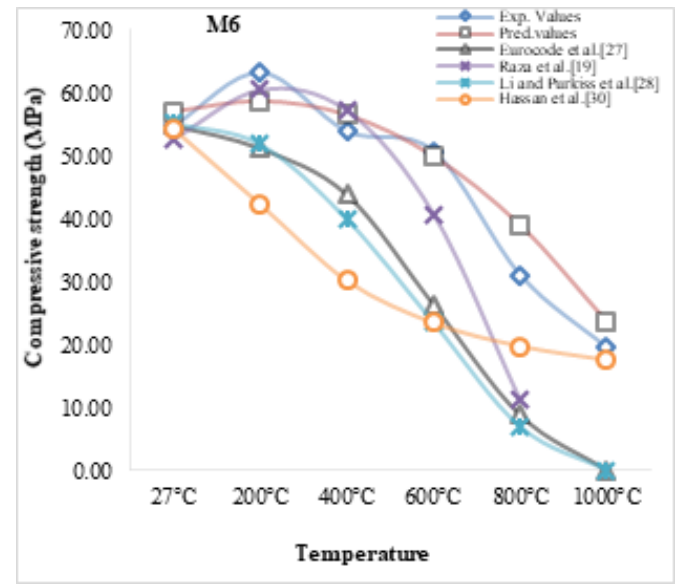

Fig 20. Compressive strength calculated from different relations w.r.t temperature for M6 mix 


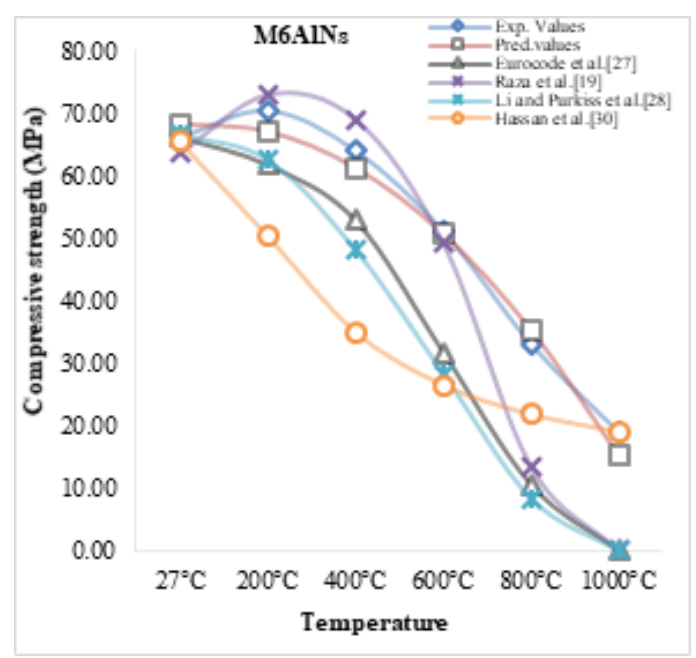

Fig 21. Compressive strength calculated from different relations w.r.t temperature for M6AlNs mix

The percentage difference between experimental and predicted values is determined for each of the concrete blends mentioned in Tables 7 and 8 . The negative sign of $\%$ error indicates that predictive values are higher than experimental values, while the positive sign indicates that predictive values are lower than experimental values. M4, M5, and M6 had a percent error of -34 to 7\%, while M4AlNs, M5AlNs, and M6AlNs had a percent error of -20 to $34 \%$. For temperatures up to $600^{\circ} \mathrm{C}$, the percent error was between -8 and 8, with the percent error being lower for M6 and M6AlNs. Therefore, the proposed relations can be used to determine the residual compressive at different temperatures.

Table 7. Error analysis for control mixes

\begin{tabular}{|c|c|c|c|c|c|c|c|c|c|}
\hline \multirow{2}{*}{$\begin{array}{l}\text { Temp. } \\
\left({ }^{\circ} \mathrm{C}\right)\end{array}$} & \multicolumn{3}{|l|}{ M4 } & \multicolumn{3}{|l|}{ M5 } & \multicolumn{3}{|l|}{ M6 } \\
\hline & Exp. values & $\begin{array}{l}\text { Pred. val- } \\
\text { ues }\end{array}$ & \% Error & $\begin{array}{l}\text { Exp. } \\
\text { values }\end{array}$ & $\begin{array}{l}\text { Pred. val- } \\
\text { ues }\end{array}$ & $\%$ Error & $\begin{array}{l}\text { Exp. } \\
\text { values }\end{array}$ & $\begin{array}{l}\text { Pred. val- } \\
\text { ues }\end{array}$ & \% Error \\
\hline 27 & 40.94 & 42.82 & $-5 \%$ & 46.95 & 49.24 & $-5 \%$ & 54.80 & 57.08 & $-4 \%$ \\
\hline 200 & 47.08 & 44.05 & $6 \%$ & 53.01 & 50.02 & $6 \%$ & 63.22 & 58.72 & $7 \%$ \\
\hline 400 & 40.82 & 42.41 & $-4 \%$ & 46.42 & 47.77 & $-3 \%$ & 53.90 & 56.53 & $-5 \%$ \\
\hline 600 & 38.81 & 37.50 & $3 \%$ & 44.66 & 42.13 & $6 \%$ & 50.77 & 49.95 & $2 \%$ \\
\hline 800 & 24.25 & 29.31 & $-21 \%$ & 24.68 & 33.12 & $-34 \%$ & 31.06 & 38.99 & $-26 \%$ \\
\hline 1000 & 18.38 & 17.85 & $3 \%$ & 22.31 & 20.72 & $7 \%$ & 19.53 & 23.65 & $-21 \%$ \\
\hline
\end{tabular}

Table 8. Error analysis for $\mathrm{Al}+\mathrm{Ns}$ mixes

\begin{tabular}{|c|c|c|c|c|c|c|c|c|c|}
\hline \multirow{2}{*}{$\begin{array}{l}\text { Temp. } \\
\left({ }^{\circ} \mathrm{C}\right)\end{array}$} & \multicolumn{3}{|l|}{ M4AlNs } & \multicolumn{3}{|c|}{ M5AlNs } & \multicolumn{3}{|c|}{ M6AlNs } \\
\hline & Exp. values & $\begin{array}{l}\text { Pred. val- } \\
\text { ues }\end{array}$ & \% Error & $\begin{array}{l}\text { Exp. } \\
\text { values }\end{array}$ & $\begin{array}{l}\text { Pred. val- } \\
\text { ues }\end{array}$ & \% Error & $\begin{array}{l}\text { Exp. } \\
\text { values }\end{array}$ & $\begin{array}{l}\text { Pred. val- } \\
\text { ues }\end{array}$ & $\%$ Error \\
\hline 27 & 52.80 & 55.87 & $-6 \%$ & 56.56 & 58.79 & $-4 \%$ & 66.15 & 68.28 & $-3 \%$ \\
\hline 200 & 58.45 & 54.55 & $7 \%$ & 60.72 & 57.77 & $5 \%$ & 70.40 & 67.09 & $5 \%$ \\
\hline 400 & 51.98 & 49.48 & $5 \%$ & 55.31 & 52.79 & $5 \%$ & 64.00 & 61.27 & $4 \%$ \\
\hline 600 & 41.32 & 40.61 & $2 \%$ & 42.78 & 43.74 & $-2 \%$ & 51.11 & 50.68 & $1 \%$ \\
\hline 800 & 23.25 & 27.94 & $-20 \%$ & 26.80 & 30.62 & $-14 \%$ & 33.03 & 35.34 & $-7 \%$ \\
\hline 1000 & 17.30 & 11.46 & $34 \%$ & 15.29 & 13.43 & $12 \%$ & 18.97 & 15.23 & $20 \%$ \\
\hline
\end{tabular}




\section{Conclusion}

The conclusions are being drawn based on the findings in the present research. The relative compressive strength was greater than 1 at $200^{\circ} \mathrm{C}$ after 4 and 8 hours, indicating an increase in strength for both control and $\mathrm{Al}+\mathrm{Ns}$ mixes. But as the temperature and fire duration increased, the relative compressive strength decreased. M4AlNs, M5AlNs, and M6AlNs mixes had the lowest relative strength of 0.08 to 0.09 at $1000^{\circ} \mathrm{C}$ for 12 hours. The relative compressive of M4AlNs, M5AlNs, and M6AlNs mixes was less compared to M4, M5, and M6 at all temperatures. As exposed to a fire for 4 and 8 hours at $200^{\circ} \mathrm{C}$, all concrete mixes had UPV values greater than 4.5 , indicating excellent quality. The ultrasonic pulse velocity reduced as the temperature and duration of the fire increased, with the percentage decrease being greater for M4AlNs, M5AlNs, and M6AlNs mixes at all temperatures. The dramatic decrease in the ultrasonic pulse velocity values of all concrete mixes beyond $400^{\circ} \mathrm{C}$ clearly showed a rapid degradation in the physical state of the concrete specimens. At $1000^{\circ} \mathrm{C}$, the ultrasonic pulse velocity values were reduced to zero for all concrete mixes due to increased porosity. The proposed equations in polynomial form had a correlation coefficient $\mathrm{R}^{2}$ almost equal to 1 for all the concrete mixes, and it showed acceptable reliability compared to other relations.

\section{Limitations}

As the temperature rose above $600^{\circ} \mathrm{C}$, the efficiency of $\mathrm{Al}+\mathrm{Ns}$ mixes decreased compared to the control mixes.

\section{Future scope}

Since lightweight aggregates have a lower heat conductivity, in future research, we can study the performance of concrete using lightweight aggregates, alccofine, and nano-silica at high temperatures.

\section{Nomenclature}

\begin{tabular}{ll}
\hline $\mathrm{RCS}$ & Relative compressive strength \\
$\mathrm{Al}$ & Alccofine \\
$\mathrm{Ns}$ & Nano-silica \\
$\mathrm{Al}+\mathrm{Ns}$ mix & Concrete using alccofine and nano-silica \\
$\mathrm{UPV}$ & Ultrasonic Pulse Velocity \\
$\mathrm{f}_{c^{\prime} T}$ & Cylindrical compressive strength at temperature ' $\mathrm{T}$ ' \\
$\mathrm{f}_{c^{\prime}} 27$ & Cylindrical compressive strength at temperature '27' $\mathrm{C}$ ' \\
$\mathrm{f}_{c^{\prime}}$ & Cylindrical compressive strength at room temperature \\
$\mathrm{T}$ & Temperature \\
\hline
\end{tabular}

\section{References}

1) Alhasanat MB, Qadi ANA, Khashman OAA, Dahamsheh A. Scanning Electron Microscopic Evaluation of Self-Compacting Concrete Spalling at Elevated Temperatures. American Journal of Engineering and Applied Sciences. 2016;9(1):119-127. Available from: https://dx.doi.org/10.3844/ajeassp.2016.119.127.

2) Metev SM, Veiko VP. Laser-assisted microtechnology. Springer. 1998. Available from: https://www.springer.com/gp/book/9783642872730.

3) Jahren PA. Fire Resistance of High Strength/Dense Concrete with Particular Reference to the Use of Condensed Silica Fume-A Review. In: Proceedings of the Third International Conference. ACI SP-114. 1989;p. 1013-1049. Available from: https:/www.concrete.org/publications/ internationalconcreteabstractsportal $/ \mathrm{m} /$ details/id $/ 2572$.

4) Balakrishnaiah D, Balaji KVGD, Srinivasa RP. Application of SEM method to investigate the cause of effect of elevated temperatures on compressive strength for ternary blended concrete using metakaolin and micro silica. ARPN Journal of Engineering and Applied Sciences. 2017;12(7):2029-2036. Available from: http://www.arpnjournals.org/jeas/research_papers/rp_2017/jeas_0417_5859.pdf.

5) Solís-Carcaño R, Moreno EI. Evaluation of concrete made with crushed limestone aggregate based on ultrasonic pulse velocity. Construction and Building Materials. 2008;22(6):1225-1231. Available from: https://dx.doi.org/10.1016/j.conbuildmat.2007.01.014.

6) Rama JK, Grewal BS. Evaluation of Efficiency of Nondestructive Testing Methods for Determining the Strength of Concrete Damaged by Fire. Advances in Structural Engineering. 2015;p. 2567-2578. Available from: https://doi.org/10.1007/978-81-322-2187-6_198.

7) Wuryanti W. Determination residual strength concrete of post-fire using ultrasonic pulse velocity. IOP Conference Series: Materials Science and Engineering. 2019;620(1). Available from: https://dx.doi.org/10.1088/1757-899x/620/1/012064.

8) Muthadhi A, Kothandaraman S. Experimental investigations on polymer-modified concrete subjected to elevated temperatures. Materials and Structures. 2014;47:977-986. Available from: https://dx.doi.org/10.1617/s11527-013-0107-4.

9) Kirchhof LD, Lorenzi A, Filho LCPS. Assessment of concrete residual strength at high temperatures using ultrasonic pulse velocity. The e-Journal of Nondestructive Testing. 2015;20(7):1-9. Available from: https://www.ndt.net/article/ndtnet/2015/1_Lari.pdf. 
10) Wróblewski R, Stawiski B. Ultrasonic Assessment of the Concrete Residual Strength after a Real Fire Exposure. Buildings. 2020;10(9):154-154. Available from: https://dx.doi.org/10.3390/buildings10090154.

11) Cruz-Hernández RA, Zapata-Orduz LE, Quintero-Ortiz LA, Herrera-Ortiz JO, , and. Physical and mechanical characterization of concrete exposed to elevated temperatures by using ultrasonic pulse velocity. Revista Facultad de Ingeniería Universidad de Antioquia. 2015;2015(75):108-129. Available from: https://dx.doi.org/10.17533/udea.redin.n75a12.

12) Belaribi H, Mellas M, Rahmani F. The relationship between the compressive strength and ultrasonic pulse velocity concrete with fibers exposed to high temperatures. International Journal of Energetica. 2016;3(1):31-36. Available from: https://dx.doi.org/10.47238/ijeca.v3i1.63.

13) Gavela S, Nikoloutsopoulos N, Papadakos G, Sotiropoulou A. Combination of compressive strength test and ultrasonic pulse velocity test with acceptable uncertainty. Material Design \& Processing Communication. 2020;(e171). Available from: https://doi.org/10.1002/mdp2.171.

14) Khodja N, Hadjab H. Effects of Elevated Temperatures on Mechanical's concrete specimen behaviour. EDP Sciences. 2018. Available from: https: //dx.doi.org/10.1051/matecconf/201816522010. doi:10.1051/matecconf/201816522010.

15) Yao W, Pang J, Liu Y. Performance Degradation and Microscopic Analysis of Lightweight Aggregate Concrete after Exposure to High Temperature. Materials. 2020;13(7):1566-1566. Available from: https://dx.doi.org/10.3390/ma13071566.

16) Hwang E, Kim G, Choe G, Yoon M, Gucunski N, Nam J. Evaluation of concrete degradation depending on heating conditions by ultrasonic pulse velocity. Construction and Building Materials. 2018;171:511-520. Available from: https://dx.doi.org/10.1016/j.conbuildmat.2018.03.178.

17) Ghosh R, Sagar SP, Kumar A, Gupta SK, Kumar S. Estimation of geopolymer concrete strength from ultrasonic pulse velocity (UPV) using high power pulser. Journal of Building Engineering. 2018;16:39-44. Available from: https://dx.doi.org/10.1016/j.jobe.2017.12.009.

18) Gyu-Yong KIM, Young-Sun KIM, Tae-Gyu LE. Mechanical properties of high-strength concrete subjected to high temperature by stressed test. Transactions of Nonferrous metals society of China. 2009;19(1):128-133. Available from: https://doi.org/10.1016/S1003-6326(10)60260-9.

19) Raza SS, Qureshi LA, Ali B, Raza A, Khan MM, Salahuddin H. Mechanical Properties of HybridSteel-Glass Fiber-Reinforced Reactive Powder Concrete AfterExposure to Elevated Temperatures. Arabian Journal for Science and Engineering. 2020;45(5):4285-4300. Available from: https://dx.doi.org/10.1007/ s13369-020-04435-4.

20) Park SJ, Yim HJ, Kwak HG. Effects of post-fire curing conditions on the restoration of material properties of fire-damaged concrete. Construction and Building Materials. 2015;99:90-98. Available from: https://doi.org/10.1016/j.conbuildmat.2015.09.015.

21) Kodur V. Properties of Concrete at Elevated Temperatures. ISRN Civil Engineering. 2014;2014:1-15. Available from: https://dx.doi.org/10.1155/2014/ 468510.

22) Ho CM, Tsai WT. Effect of Elevated Temperature on the Strength and Ultrasonic Pulse Velocity of Glass Fiber and Nano-Clay Concrete. Advanced Materials Research. 2010;p. 1532-1539. Available from: https://doi.org/10.4028/www.scientific.net/amr.163-167.1532.

23) Hager. Behaviour of cement concrete at high temperature. Bulletin of the polish academy of sciences, Technical sciences. 2003;61(1):1-10. Available from: https://doi.org/10.2478/bpasts-2013-0013.

24) Demirel B, Keleştemur O. Effect of elevated temperature on the mechanical properties of concrete produced with finely ground pumice and silica fume. Fire Safety Journal. 2010;45(6-8):385-391. Available from: https://dx.doi.org/10.1016/j.firesaf.2010.08.002.

25) Arel HŞ, Shaikh FUA. Effects of silica fume fineness on mechanical properties of steel fiber reinforced lightweight concretes subjected to ambient and elevated temperatures exposure. Structural Concrete. 2018;19:1829-1837. Available from: https://dx.doi.org/10.1002/suco.201700281.

26) 26.BS 1881: Part 120: 1983, Method for Determination of Compressive Strength of Concrete Cores. 1983.

27) Eurocode: BS EN 1992-2:2005-Eurocode 2: design of concrete structures-part 2: concrete bridges-design and detailing rules. 1992.

28) yuan Li L, Purkiss J. Stress-strain constitutive equations of concrete material at elevated temperatures. Fire Safety Journal. 2005;40:669-686. Available from: https://dx.doi.org/10.1016/j.firesaf.2005.06.003.

29) Pachideh G, M G. An experimental into effect of temperature rise on mechanical and visual characteristics of concrete containing recycled metal spring. Structural Concrete. 2020;p. 1-16. Available from: https://doi.org/10.1002/suco.201900274.

30) Hassan A, Arif M, Shariq M. Mechanical Behaviour and Microstructural Investigation of Geopolymer Concrete After Exposure to Elevated Temperatures. Arabian Journal for Science and Engineering. 2020;45(5):3843-3861. Available from: https://dx.doi.org/10.1007/s13369-019-04269-9. 